\title{
Comparison of health supplement on strength, stamina and growth of rats
}

\author{
Swanand S. Pathak, Nikhil S. Yadav*
}

Department of Pharmacology, Jawaharlal Medical college, Sawangi, Wardha, Maharashtra, India

Received: 24 January 2019 Accepted: 27 February 2019

*Correspondence to:

Dr. Nikhil S. Yadav,

Email: mysticfugue@gmail.com

Copyright: (C) the author(s), publisher and licensee Medip Academy. This is an openaccess article distributed under the terms of the Creative Commons Attribution NonCommercial License, which permits unrestricted noncommercial use, distribution, and reproduction in any medium, provided the original work is properly cited.

\begin{abstract}
Background: Children require more nutrition as organs grow fast in this age group. Due to abundance of various commercial health supplements in market, parents are often confused about selection of health supplements. Traditional foods are rich source of various nutrients required by growing children. We conducted a study to compare strength, stamina and growth enhancing ability of commercial health supplement and natural health supplement on wistar rats.

Methods: Total of 24 wistar rats were included. Animals were divided in four groups. Each group of rats except control group were receiving health supplements. Group I, group II, group III and group IV were receiving health supplement I, health supplement II, natural health supplement and no health supplement (control group) for 60 days. Strength and stamina of wistar rats in each group were analysed using grip strength meter and swim stress test, growth of rats in each group were analysed by measuring body length, tail length and body weight. Group of rat showing maximum growth (body length, tail length and body weight), strength and stamina were analysed.

Results: Group II rats showed greater strength and stamina followed by group I, group III and group IV respectively. Group I rats showed maximum growth followed by group II, group III and group IV respectively.

Conclusions: In the current study we found that strength and stamina were greater in group II rats followed by group I, group III and group IV respectively also group I rats showed maximum growth followed by group II, group III and group IV respectively.
\end{abstract}

Keywords: Growth, Health supplement, Strength, Stamina

\section{INTRODUCTION}

Strength , stamina and growth is important for survival and perpetuation of human beings and other animals. Traditional food has always been considered for curbing fatigue increasing strength, stamina and accelerating growth. Limited strength and stamina may lead to fatigue, a complex phenomenon that can be described as 'time dependent - exercise induced reduction in the maximal force generation capacity of a muscle'. ${ }^{1}$ With extreme pace of life and cut throat competition children oftenly get fatigue and their growth is also affected therefore a wellbalanced dietary supplement along with proper food is necessary. ${ }^{2}$ Organs of preschool children grow fastest therefore proper nutrition is very much necessary during this period to cope up with increasing demand of the body. ${ }^{3}$ Modern health supplements come with fortified nutrients and sugars, they are slightly expensive due to which many under privileged families in developing country like India can't afford them. Attraction of children and adolescents towards energy drinks had led to increase adverse health effects on them. ${ }^{4}$ Due to exemption of dietary supplements from drugs and food regulation, the use of commercial dietary supplement has grown substantially. ${ }^{5}$ The quest for safe and effective health supplements has drawn the attention of researchers towards traditional health supplements. ${ }^{6}$ Legumes and soybeans are rich sources of 
proteins for poor children in developing country like India, which can provide recommended dietary proteins at a cost which is affordable for poor population. ${ }^{7}$ A combination of natural foods like Puffed rice, groundnut, soybeans, salt ,glucose etc in a specific concentration is helpful in supplementing growth and increasing stamina of growing children. ${ }^{8}$

Natural foods increase strength and stamina by providing essential nutrients for growth and development. The present study is therefore undertaken to compare and study the strength, stamina and growth enhancing properties of health supplements prepared from natural foods and two commercially available health supplements in growing wistar rats

Aim of the present study is to compare effect of natural and commercial health supplements on strength, stamina and growth of wistar rats.

\section{Objectives}

- To evaluate the strength, stamina and growth effects of natural health supplement on wistar rats .

- To evaluate the strength, stamina and growth effects of health supplement I and health supplement II on wistar rats.

- To compare effects of health supplement I with health supplement II and natural health supplement on strength, stamina and growth in wistar rats.

\section{METHODS}

The study was undertaken after receiving letter of approval from Institutional Animals Ethics Committee (IAEC). The study was performed on 24 wistar rats aged 20 to 22 days. The study was conducted from $1^{\text {st }}$ March 2017 till $1^{\text {st }}$ May 2017 for 60 days at animal house of JNMC Sawangi. Inclusion criteria for this study were growing wistar rats aged 20 to 22 days of either sex weighing 50 to $70 \mathrm{gms}$ and body length 22.5 and $25 \mathrm{cms}$ were used in this study. Total 24 wistar rats were included in the study. Animals were randomly divided in four groups with 6 rats in each group. Each group of rats except control group were receiving health supplements (traditional or commercial) in addition to normal diet and water.

Group I was receiving commercial health supplement I, group II rats received commercial health supplement II for 60 days, group III rats received natural health supplement (mixture of groundnut, soybeans, salt, sugar, puffed rice) for 60 days, group IV rats were not given any supplement and were the control group. Strength and stamina of wistar rats in each group were analysed using grip strength meter (Newton) and swim stress test (seconds) at $60^{\text {th }}$ day respectively and compared with other groups, growth of rats in each group were analysed by measuring body length $(\mathrm{cms})$, tail length (cms) and body weight (gms) at $60^{\text {th }}$ day and compared with other groups. Out of the four groups, group of rat showing maximum growth (body length, tail length and body weight), maximum strength on grip strength meter (Newtons) and maximum stamina on swim stress test (seconds) were analysed statistically. A force transducer equipped with a metal bar was used to measure the amount of tensile force by each mouse. We grasped the mouse at the base of the tail and lowered it vertically towards the bar. The mouse was pulled slightly backwards by the tail while the two paws (forelimbs) grasped the bar, which triggered a "counter pull." This grip strength meter recorded the grasping force in newton.

Table 1: Experimental animals were grouped.

\begin{tabular}{|ll|}
\hline Group & Supplements Given \\
\hline I & Commercial Health supplement I \\
\hline II & Commercial health supplement II \\
\hline III & Natural health supplement \\
\hline IV & Control Group \\
\hline
\end{tabular}

Group I, group II, group III and group IV rats were receiving Commercial health supplement I, commercial health supplement II, Natural health supplement and no health supplement respectively as shown in Table 1.

All rats were kept under observation for 1 week prior to the experiment to permit the animals to adjust to the environment. Supplements were given through mixing respective health supplement with water in 1:1 ratio and giving $2 \mathrm{ml}$ through oral gavage. Growth of wistar rats of each group were recorded on $60^{\text {th }}$ day respectively through measurement of body length and tail length $(\mathrm{cms})$ and weight (gms). Strength was recorded through grip strength meter by testing the strength in forelimbs of wistar rats (newtons) and stamina was recorded through swim stress test(ability to swim in water before sinking).

\section{Statistical analysis}

Statistical analysis was done by using descriptive and inferential statistics using one way ANOVA and Multiple comparison Tukey Test and software used in the analysis was SPSS 22.0 version and $\mathrm{p}<0.05$ is considered as level of significance.

\section{RESULTS}

Mean body weight of wistar rats were $56.08 \mathrm{gms}, 59.83$ gms, 55 gms, 58.75 gms in group I,II,III and IV respectively, Mean body length of wistar rats were 24 cms, $24 \mathrm{cms}, 23.5 \mathrm{cms}$ gms, $23.83 \mathrm{cms}$ in group I, II, III and IV respectively, Mean tail length of wistar rats were 11.58 cms, $11.66 \mathrm{cms}, 11.58 \mathrm{cms}, 11.41 \mathrm{cms}$ in group I, II, III and IV respectively, Mean duration of swim stress test of wistar rats were 30.33 secs, 30 secs cms, $30.16 \mathrm{cms}, 30.33$ secs in group I, II, III and IV respectively, Mean grip strength of wistar rats were $0.34 \mathrm{~N}, 0.33 \mathrm{~N}, 0.28 \mathrm{~N}, 0.32 \mathrm{~N}$ in group I, II, III and IV respectively before giving supplements (Table 2). 
Table 2: Mean body weight, length, tail length, duration of swim stress test and mean grip strength of wistar rats before giving supplements.

\begin{tabular}{|lllll|}
\hline At 0 day & Group I & $\begin{array}{l}\text { Group } \\
\text { II }\end{array}$ & $\begin{array}{l}\text { Group } \\
\text { III }\end{array}$ & $\begin{array}{l}\text { Group } \\
\text { IV }\end{array}$ \\
\hline $\begin{array}{l}\text { Mean body } \\
\text { weight (gms) }\end{array}$ & $\begin{array}{l}56.08 \\
\text { gms }\end{array}$ & $\begin{array}{l}59.83 \\
\text { gms }\end{array}$ & $\begin{array}{l}55 \\
\text { gms }\end{array}$ & $\begin{array}{l}58.75 \\
\text { gms }\end{array}$ \\
\hline $\begin{array}{l}\text { Mean body } \\
\text { length (cms) }\end{array}$ & $24 \mathrm{cms}$ & $24 \mathrm{cms}$ & $\begin{array}{l}23.50 \\
\mathrm{cms}\end{array}$ & $\begin{array}{l}23.83 \\
\mathrm{cms}\end{array}$ \\
\hline $\begin{array}{l}\text { Mean tail } \\
\text { length (cms) }\end{array}$ & 11.58 & 11.66 & 11.58 & 11.41 \\
\hline $\begin{array}{l}\text { Mean } \\
\text { duration of }\end{array}$ & 30.33 & cms & cms & $\mathrm{cms}$ \\
$\begin{array}{l}\text { swim stress } \\
\text { test (secs) }\end{array}$ & secs & $30 \mathrm{secs}$ & $\begin{array}{l}30.16 \\
\mathrm{secs}\end{array}$ & $\begin{array}{l}30.33 \\
\mathrm{secs}\end{array}$ \\
\hline $\begin{array}{l}\text { Mean grip } \\
\text { strength } \\
\text { (newtons) }\end{array}$ & $0.34 \mathrm{~N}$ & $0.33 \mathrm{~N}$ & $0.28 \mathrm{~N}$ & $0.32 \mathrm{~N}$ \\
\hline
\end{tabular}

Mean body weight (gms) after 60 days in group I was $177.83 \pm 7.87$ (gms), in group II it was $125.41 \pm 3.16$ (gms), in group III it was $104.50 \pm 3.61$ (gms), in group IV it was $102.91 \pm 3.04$ (gms). By using one way ANOVA statistically significant difference was found in mean body weight (gms) of four groups $(\mathrm{F}=310.93$, $\mathrm{p}$ value $=0.0001$. On comparing body weight in between four groups using Multiple comparison Tukeys test, significant difference was found in between all groups ( $p$ value $<0.05$ ) except in between group III and group IV (Table 3 ).

Mean body length (cms) at 60th day in group I was $37.33 \pm 0.51$ (cms), in group II it was $32.16 \pm 0.75(\mathrm{cms})$, in group III it was $30.25 \pm 0.75$ (cms), in group IV it was $29 \pm 1.41$ (cms). By using one way ANOVA statistically significant difference was found in mean body length $(\mathrm{cms})$ of four groups $(\mathrm{F}=94.81$, $\mathrm{p}$ value $=0.0001)$. On comparing body length in between four groups using Multiple comparison Tukeys test, significant difference was found in between all groups ( $p$ value $<0.05$ ) except in between group III and group IV (Table 4).

Mean tail length (cms) at 60th day in group I was $16.75 \pm 0.41(\mathrm{cms})$, in group II it was $15.50 \pm 0.54$ (cms), in group III it was $14.83 \pm 0.40$ (cms), in group IV it was $14 \pm 0.70$ (cms). By using one way ANOVA statistically significant difference was found in mean body length $(\mathrm{cms})$ of four groups $(\mathrm{F}=28.358$, $\mathrm{p}$ value $=0.0001)$.

Table 3: Comparison of body weight (gms) in four groups.

\begin{tabular}{|c|c|c|c|c|c|c|c|c|c|}
\hline \multirow[t]{2}{*}{ Groups } & & \multirow[t]{2}{*}{$\mathbf{N}$} & \multirow[t]{2}{*}{ Mean } & \multirow{2}{*}{$\begin{array}{l}\text { Std. } \\
\text { deviation }\end{array}$} & \multirow{2}{*}{$\begin{array}{l}\text { Std. } \\
\text { Error }\end{array}$} & \multicolumn{2}{|c|}{$\begin{array}{l}95 \% \text { Confidence Interval } \\
\text { for Mean }\end{array}$} & \multirow{2}{*}{ Minimum } & \multirow[t]{2}{*}{ Maximum } \\
\hline & & & & & & Lower bound & Upper bound & & \\
\hline \multirow{4}{*}{$\begin{array}{l}\text { At } \\
60^{\text {th }} \text { day }\end{array}$} & Group I & 6 & 177.83 & 7.87 & 3.21 & 169.56 & 186.10 & 172.00 & 193.50 \\
\hline & Group II & 6 & 125.41 & 3.16 & 1.29 & 122.09 & 128.74 & 122.00 & 131.00 \\
\hline & Group III & 6 & 104.50 & 3.61 & 1.47 & 100.70 & 108.29 & 100.00 & 110.00 \\
\hline & Group IV & 6 & 102.91 & 3.04 & 1.24 & 99.72 & 106.107 & 100.00 & 108.00 \\
\hline
\end{tabular}

Table 4: Comparison of body length (cms) in four groups.

\begin{tabular}{|c|c|c|c|c|c|c|c|c|c|}
\hline \multirow{2}{*}{ Groups } & & \multirow[t]{2}{*}{$\mathbf{N}$} & \multirow[t]{2}{*}{ Mean } & \multirow{2}{*}{$\begin{array}{l}\text { Std. } \\
\text { deviation }\end{array}$} & \multirow{2}{*}{$\begin{array}{l}\text { Std. } \\
\text { Error }\end{array}$} & \multicolumn{2}{|c|}{$\begin{array}{l}95 \% \text { Confidence Interval for } \\
\text { Mean }\end{array}$} & \multirow[t]{2}{*}{ Minimum } & \multirow[t]{2}{*}{ Maximum } \\
\hline & & & & & & Lower bound & Upper bound & & \\
\hline \multirow{4}{*}{$\begin{array}{l}\text { At } 60^{\text {th }} \\
\text { day }\end{array}$} & Complan & 6 & 37.33 & 0.51 & 0.21 & 36.79 & 37.87 & 37.00 & 38.00 \\
\hline & Pedia Sure & 6 & 32.16 & 0.75 & 0.30 & 31.37 & 32.95 & 31.00 & 33.00 \\
\hline & $\begin{array}{l}\text { Health } \\
\text { supplement }\end{array}$ & 6 & 30.25 & 0.75 & 0.30 & 29.45 & 31.04 & 29.00 & 31.00 \\
\hline & Control & 6 & 29.00 & 1.41 & 0.57 & 27.51 & 30.48 & 27.00 & 31.00 \\
\hline
\end{tabular}

Table 5: Comparison of tail length (cms) in four groups.

\begin{tabular}{|c|c|c|c|c|c|c|c|c|c|}
\hline \multirow[t]{2}{*}{ Groups } & & \multirow[t]{2}{*}{$\mathbf{N}$} & \multirow[t]{2}{*}{ Mean } & \multirow{2}{*}{$\begin{array}{l}\text { Std. } \\
\text { deviation }\end{array}$} & \multirow{2}{*}{$\begin{array}{l}\text { Std. } \\
\text { Error }\end{array}$} & \multicolumn{2}{|c|}{$\begin{array}{l}95 \% \text { Confidence Interval } \\
\text { for Mean }\end{array}$} & \multirow[t]{2}{*}{ Minimum } & \multirow[t]{2}{*}{ Maximum } \\
\hline & & & & & & Lower bound & Upper boun & & \\
\hline \multirow{4}{*}{$\begin{array}{l}\text { At } \\
60^{\text {th }} \text { day }\end{array}$} & Group I & 6 & 16.75 & 0.41 & 0.17 & 16.31 & 17.18 & 16.00 & 17.00 \\
\hline & Group II & 6 & 15.50 & 0.54 & 0.22 & 14.92 & 16.07 & 15.00 & 16.00 \\
\hline & Group III & 6 & 14.83 & 0.40 & 0.16 & 14.40 & 15.26 & 14.00 & 15.00 \\
\hline & Group IV & 6 & 14.00 & 0.70 & 0.28 & 13.25 & 14.74 & 13.00 & 15.00 \\
\hline
\end{tabular}


On comparing tail length in between four groups using Multiple comparison Tukeys test, significant difference was found in between all groups (p value $<0.05$ ) except in between group 3 and group 4 and also in between group 2 and group 3 (Table 5).

Table 6: Comparison of swim stress test duration (seconds) in four groups.

\begin{tabular}{|c|c|c|c|c|c|c|c|c|c|}
\hline \multirow[t]{2}{*}{ Groups } & & \multirow[t]{2}{*}{$\mathbf{N}$} & \multirow[t]{2}{*}{ Mean } & \multirow{2}{*}{$\begin{array}{l}\text { Std. } \\
\text { deviation }\end{array}$} & \multirow{2}{*}{$\begin{array}{l}\text { Std. } \\
\text { Error }\end{array}$} & \multicolumn{2}{|c|}{$\begin{array}{l}95 \% \text { Confidence Interval } \\
\text { for Mean }\end{array}$} & \multirow{2}{*}{ Minimum } & \multirow[t]{2}{*}{ Maximum } \\
\hline & & & & & & Lower bound & Upper boun & & \\
\hline \multirow{4}{*}{$\begin{array}{l}\text { At } \\
60^{\text {th }} \text { day }\end{array}$} & Group I & 6 & 86.16 & 2.92 & 1.19 & 83.09 & 89.23 & 82.00 & 89.00 \\
\hline & Group II & 6 & 106.83 & 6.52 & 2.66 & 99.98 & 113.68 & 98.00 & 115.00 \\
\hline & Group III & 6 & 70.66 & 1.21 & 0.49 & 69.39 & 71.93 & 69.00 & 72.00 \\
\hline & Group IV & 6 & 66.16 & 3.43 & 1.40 & 62.56 & 69.76 & 60.00 & 69.00 \\
\hline
\end{tabular}

Table 7: Comparison of grip strength (Newton) in four groups.

\begin{tabular}{|c|c|c|c|c|c|c|c|c|c|}
\hline \multirow{2}{*}{ Groups } & & \multirow[t]{2}{*}{$\mathbf{N}$} & \multirow{2}{*}{ Mean } & \multirow{2}{*}{$\begin{array}{l}\text { Std. } \\
\text { deviation }\end{array}$} & \multirow{2}{*}{$\begin{array}{l}\text { Std. } \\
\text { Error }\end{array}$} & \multicolumn{2}{|c|}{$\begin{array}{l}\text { 95\% Confidence Interval } \\
\text { for Mean }\end{array}$} & \multirow{2}{*}{ Minimum } & \multirow[t]{2}{*}{ Maximum } \\
\hline & & & & & & Lower bound & Upper boun & & \\
\hline \multirow{4}{*}{$\begin{array}{l}\text { At } \\
60^{\text {th }} \text { day }\end{array}$} & Group I & 6 & 0.59 & 0.02 & 0.01 & 0.56 & 0.62 & 0.58 & 0.65 \\
\hline & Group II & 6 & 0.67 & 0.01 & 0.007 & 0.65 & 0.69 & 0.65 & 0.69 \\
\hline & Group III & 6 & 0.45 & 0.02 & 0.008 & 0.42 & 0.47 & 0.42 & 0.47 \\
\hline & Group IV & 6 & 0.39 & 0.02 & 0.009 & 0.37 & 0.41 & 0.36 & 0.42 \\
\hline
\end{tabular}

Mean swim stress test at $60^{\text {th }}$ day in group I was $86.16 \pm 2.92$ (seconds), in group II it was 106.83 \pm 6.52 (seconds), in group III it was $70.66 \pm 1.21$ (seconds), in group IV it was $66.16 \pm 3.43$ (seconds). By using one way ANOVA statistically significant difference was found in mean body length $(\mathrm{cms})$ of four groups $(\mathrm{F}=125.82$, $\mathrm{p}$ value=0.0001). On comparing duration of swim stress test in between four groups using Multiple comparison Tukeys test, significant difference was found in between all groups ( $p$ value $<0.05$ ) except in between group III and group IV (Table 6).

Mean grip strength at 60th day in group I was $0.59 \pm 0.02$ (Newton), in group II it was $0.67 \pm 0.01$ (Newton), in group III it was $0.45 \pm 0.02$ (Newton), in group IV it was $0.39 \pm 0.02$ (Newton). By using one way ANOVA statistically significant difference was found in mean body length $(\mathrm{cms})$ of four groups $(\mathrm{F}=193.02$, $\mathrm{p}$ value $=0.0001)$. On comparing duration of swim stress test in between four groups using Multiple comparison Tukeys test, significant difference was found in between all groups ( $p$ value $<0.05$ ) (Table 7).

\section{DISCUSSION}

The rate of growth and weight gain of growing rats can be altered by giving them health supplements along with normal diet. In present study out of 24 rats two group of rats were given health supplement I and health supplement II respectively, one group was given natural health supplement, one group was control group which was not given any health supplement. All parameters were measured initially before giving any health supplements and at $60^{\text {th }}$ day. Length of rats were measured from nose till tail end at the end of the tail. Statistically significant difference in mean body length was found in between Group I (37.33 cms), group II $(32.16 \mathrm{cms})$, group III (30.25 $\mathrm{cms})$ and group IV $(29 \mathrm{cms})$ at $60^{\text {th }}$ on multiple comparison Tukey's test (except in between group III and group IV rats).

Group I rats had significant body growth followed by group II. In present study group I rats had greater growth of tail length $(16.75 \mathrm{cms})$ which showed statistically significant difference with tail growth of group II $(15.50 \mathrm{cms})$, group III $(14.83 \mathrm{cms})$ and group IV $(14 \mathrm{cms})$ rats on multiple comparison Tukey test, however no statistically significant difference was found in between tail growth of group II, group III and group IV rats $(\mathrm{p}>0.05)$. While comparing increase in the body weight (gms) group I(177.83 gms) rats had statistically significant increase in body weight followed by group II rats (125.41 gms), however no significant increase in body weight was observed between group 3 (104.50 gms) and group 4 rats (102.91 gms). In one study by Galik et al, rats who were given highest quantity of bee pollens as supplement had significant increase in body weight, however in our study natural health supplement did not had weight increasing property. ${ }^{9}$

In present study rats of group II demonstrated statistically significant difference on swim stress test (106.83 secs) followed by group I (86.16 secs) followed by group III (70.66 secs) on multiple comparison Tukey test at $60^{\text {th }}$ day. Rats of group II demonstrated maximum stamina followed by rats of group I followed by group III and group IV ,there was no statistically significant difference between duration on swim stress test between group III and group IV rats. 
Group II rats taking health supplement II demonstrated enhanced stamina as compared to group I rats taking health supplement I, group III rats taking natural health supplement however were not able to demonstrate significant change in stamina on swim stress test. In one study on effects of resveratrol by Kan NW et al, on middle age rats, rats taking resveratrol as a supplement showed significant increase in stamina on swim stress test, in our study also rats taking commercial health supplements showed significant increase in stamina on swim stress test however in present study authors used fortified supplement unlike this study which used resveratrol as a supplement. ${ }^{10}$

In one study by Gupta et al, on strength and endurance of rats using swim stress test, rats receiving ratnaprash (a natural supplement) demonstrated increase endurance on swim stress test and decrease blood lactate level, however in present study rats fed with natural health supplement dint showed significant increase in stamina via swim stress test. ${ }^{6}$

In present study rats of group II demonstrated increased strength on grip strength meter followed by group I, group III and group IV respectively, there was significant statistical difference between all the groups on multiple comparison Tukey test, in one study by Liu Y et al, mice fed with actinia arguata crude alkaloids demonstrated greater endurance of fore limbs on grip strength meter as compared to mice of control group..$^{11}$

\section{CONCLUSION}

In current study authors found that commercial health supplement I has greater body growth enhancing property than commercial health supplement II followed by natural health supplement. Health supplement I was found to be superior in context of tail growth enhancing property and weight gained followed by health supplement II and natural health supplement, however both i.e. health supplement II and traditional health supplement showed equal tail growth enhancing property and weight gaining property. Present study demonstrated increased stamina and strength enhancing property of health supplement II followed by health supplement I followed by natural health supplement.

Funding: No funding sources Conflict of interest: None declared

Ethical approval: The study was approved by the Institutional Ethics Committee DMIMS Ref No. 571a/CPCSEA

\section{REFERENCES}

1. Gandevia SC. Spinal and supraspinal factors in human muscle fatigue. Physiol Rev. 2001 Oct;81(4):1725-89.

2. Xu M, Liang R, Li Y, Wang J. Anti-fatigue effects of dietary nucleotides in mice. Food Nutr Res. 2017 Jan;61(1):1334485.

3. Kim HS, Lee HY, Kim MK. Dietary Supplements Use and Related Factors of Preschoolers in 3 Korean Cities. Pediatr Gastroenterol Hepatol Nutr. 2013 Jun;16(2):104-15.

4. Seifert SM, Schaechter JL, Hershorin ER, Lipshultz SE. Health Effects of Energy Drinks on Children, Adolescents, and Young Adults. Pediatrics. 2011 Mar;127(3):511-28.

5. van Breemen RB. Development of Safe and Effective Botanical Dietary Supplements. J Med Chem. 2015 Nov 12;58(21):8360-72.

6. Gupta A, Kumar S, Rajput R, Srivastava R, Rai RK, Sastry JLN. Evaluation of Ratnaprash for its effect on strength, stamina and fatigue using swim endurance test and biochemical estimation in swiss albino mice. Anc Sci Life. 2015 Sep;35(1):26-31.

7. Yao DN, Kouassi KN, Erba D, Scazzina F, Pellegrini $\mathrm{N}$, Casiraghi MC. Nutritive Evaluation of the Bambara Groundnut Ci12 Landrace [Vigna subterranea (L.) Verdc. (Fabaceae)] Produced in Côte d'Ivoire. Int J Mol Sci. 2015 Sep 7;16(9):21428-41.

8. Boskabadi H, Bagheri S. Comparison between infants receiving traditional supplements (camel thorn, flix weed, and sugar water) and exclusively breast fed infants. Avicenna J Phytomedicine. 2015;5(6):479-84.

9. Gálik B, Bíro D, Šimko M, Juráček M, Capcarová M, Kolesárová A, et al. The effect of dietary bee pollen intake on growth performance and biochemical indicators of rats. Acta Vet Brno. 2016;85(1):99-104.

10. Kan NW, Ho CS, Chiu YS, Huang WC, Chen PY, Tung YT, et al. Effects of Resveratrol Supplementation and Exercise Training on Exercise Performance in Middle-Aged Mice. Molecules. 2016 May 18;21(5).

11. Liu Y, Liu C. Antifatigue and increasing exercise performance of Actinidia arguta crude alkaloids in mice. J Food Drug Anal. 2016;24(4):738-45.

Cite this article as: Pathak SS, Yadav NS.

Comparison of health supplement on strength, stamina and growth of rats. Int $\mathrm{J}$ Basic Clin Pharmacol 2019;8:806-10. 